PART 3

Muslim Responses to Christianity 
Asma Afsaruddin - 9789004274761

Downloaded from Brill.come4/26/2023 12:14:05PM via free access 


\title{
The Messiah 'Isa, Son of Mary: Jesus in the Islamic Tradition
}

\author{
Asma Afsaruddin
}

\begin{abstract}
Although Abraham is considered the common progenitor of the world's three monotheistic religions, Jesus may be considered the central figure in defining their relationship to one another. Jews reject him as the promised Messiah, Christians embrace him as their Redeemer, and Muslims both accept him as a messianic prophet and reject him as a savior. The status of Jesus in these three religious traditions is therefore critical in demarcating their outer boundaries in relation to one another. Until not too long ago, it was assumed that these were essentially antagonistic positions, incapable of amelioration. As Jews, Christians, and Muslims increasingly co-habit today, however, many of these positions have softened and each is willing to listen to the other's perspective as a way of illuminating one's own. In this essay, I will discuss Muslim perceptions of Jesus as shaped by foundational religious texts within Islam and the larger, internally diverse Islamic tradition, in the context of Christian-Muslim conversations on the importance of Jesus in each religion. Muslim and Christian valorizations of the servant of God, whom both call the Messiah (Christ), will thus be seen as both distinctive and as sharing many common features, which will consequently allow for Jesus to emerge not as a divisive figure but as one who creates opportunities for greater appreciation of the other's tradition.
\end{abstract}

\section{Jesus in the Qur'an}

The name Jesus, 'Isa in Arabic, is mentioned twenty-five times in the Qur'an. Al-Masih 'Isa, or Jesus the Messiah (Christ), is a Qur'anic prophet in a long line of prophets, sent by God to an erring humanity over time. This point is underscored through the frequent mention of Jesus' name in connection with other biblical prophets in the Quran. Jesus is therefore part of a long line of prophets, who were righteous men sent by God through time to various communities in order to preach an unchanging divine message of monotheism and to bring an erring humanity back to the primordial religion of islam, understood in a non-confessional sense of surrender to the one universal God. Jesus is also 
among a select group of prophets who were given a specific revelation that constituted the proofs for the truth of their mission. Thus Qur'an 2:87 states: "And truly We gave to Moses the Books and We caused a train of messengers to follow after him, and We gave to Jesus, son of Mary, clear proofs and We supported him with the holy spirit." The holy spirit (al-ruh al-qudus) is glossed in the exegetical literature as a reference to the angel Gabriel, ${ }^{1}$ who was also the bearer of heavenly revelation to the Prophet Muhammad.

The revelation vouchsafed to Jesus is specifically termed the Injil or the Gospel, and, like the Qur'an, it does not represent a supersession or abrogation of previous revelations, but rather, is considered a confirmation. Thus, Qur'an 5:46 says:

We caused Jesus, son of Mary, to follow in their footsteps, confirming what was before him, and We bestowed on him the Gospel in which there is guidance and light, confirming that which was before it in the Torah-a guidance and a reminder to those who are careful.

In fact, the Qur'an instructs the Prophet Muhammad to declare to his listeners that Muslims must believe in the prior revelations vouchsafed to God's messengers, who are equally righteous and blameless. The equality of God's messengers is a recurrent theme in the Qur'an and in the Islamic tradition, even though a number of medieval Muslim theologians went on to articulate a doctrine of supersessionism ${ }^{2}$ vis-à-vis the Jewish and Christian scriptures, ${ }^{3}$ in explicit defiance of verses such as Qur'an 3:84:

1 See, for example, al-Tabari, Jami' al-bayan fi ta'wil al-qur'an (Beirut: Dar al-kutub al-ilmiyya, 1997), 1:448-449. Al-Tabari notes, however, a minority viewpoint that regarded the holy spirit as a reference to the Gospel that strengthened Jesus.

2 Supersessionism (naskh in Arabic) is a doctrine that developed among a considerable number of medieval Muslim theologians, according to which Islam abrogates the validity of Judaism and Christianity before it. For a critique of this position as contrary to the Qur'an, see my article "The Hermeneutics of Inter-Faith Relations: Retrieving Moderation and Pluralism as Universal Principles in Qur’anic Exegeses," Journal of Religious Ethics 37 (2009): $331-54$.

3 See, for example, Ibn Taymiyya, al-Tafsir al-kabir, ed. 'Abd al-Rahman 'Umayra (Beirut: Dar al-kutub al-ilmiyya, n.d.), 4:136-138, where he discounts the possibility that Jews and Christians may still hope for salvation on the basis of their religions, despite the occurrence of Qur'anic verses 2:62 and 3:69, which state the opposite, for he maintains that these religions have been corrupted since their formative period. In addition to supersession, some 
Say: We believe in God and what is revealed to us and what was revealed to Abraham and Ishmael and Isaac and Jacob and the tribes, and what was entrusted to Moses and Jesus and the prophets from their Lord. We make no distinction between any of them, and to Him we have surrendered (muslimun). ${ }^{4}$

The Qur'an further asserts that all the prophets submitted to a similar covenant with God, and each proclaimed the same essential message. Accordingly, the sectarian divisiveness among humans is a result of their faulty understanding over time of the divine eternal message, which was faithfully conveyed by all of God's apostles. Thus, Qur'an 33:7-8 states:

And when We exacted a covenant from the Prophets, and from you (O Muhammad) and from Noah and Abraham and Moses and Jesus, son of Mary. We took from them a solemn covenant; that He may ask the loyal of their loyalty. And He has prepared a painful doom for the unfaithful.

And again, Qur’an 42:13 states:

He has ordained for you that religion which He commended to Noah, and that which We inspire in you (referring to Muhammad), and that which We commended to Abraham and Moses and Jesus, saying, "Establish the religion and do not be divided in it."

Jesus, like all the prophets preceding him, is thus innocent of the theological wrangling that ensued among his followers and the followers of other prophets, and furthermore, the Qur'an affirms that there is no fundamental disjunction between the Judeo-Christian revelation and the Islamic one. ${ }^{5}$ Jesus was granted the proofs and the necessary wisdom to invite all to follow the straight path, which represents God's primordial religion, as stated in Qur'an 43:63-64:

(by no means all) pre-modern theologians have focused on the alleged corruption (tahrif) of Jewish and Christian scriptures to posit the superiority of Islam.

4 For a discussion of inclusivist and exclusivist understandings of this verse and of the term Islam itself, see Abdulaziz Sachedina, The Islamic Roots of Democratic Pluralism (Oxford: Oxford University Press, 2001), 38-40.

5 The Qur'an frequently refers to itself as confirming (musaddiq) the previous revelations vouchsafed to the People of the Book (cf., for example, $2: 41 ; 2: 91 ; 3: 3 ; 3: 50 ; 5: 48 ; 35: 31$, etc.). 
When Jesus came with the proofs, he said, "I have come to you with wisdom, so as to make clear to you that regarding which you used to differ. So worship God and obey me. Indeed, God is my Lord and your Lord, so serve Him; this is the straight path."

These Qur'anic passages are reminiscent of Matthew 11:19, in which Jesus is described as being filled with wisdom, as well as of John 20:17 and Matthew 7:13f., in which he exhorts people to follow the narrow and straight way, which is the path of God. ${ }^{6}$

Jesus, as a Quranic exemplar, is presented as a prophet, a teacher, and a humble servant of God. He is also above all a human being whose biographical details constitute some of the most moving passages in the Qur'an. Through the emotive accounts of Jesus' birth and his brave and almost implausible defense of his chaste and helpless mother, the Qur'an establishes God's deep solicitude for the infant Jesus and his single mother. There are several references to the birth of Jesus in the Qur'an; the lengthiest and one of the most evocative accounts of the dramatic circumstances of Jesus' birth are recorded in the nineteenth chapter, which is wholly devoted to Mary and titled Surat Maryam, in verses 16-34. These verses embody powerful language to convey the significance of this seminal event and to elicit a sense of deep compassion in reference to a defenseless young mother and her child. The bond between them is portrayed as stronger than the usual mother-child relationship, for they are described as also being direct agents in the unfolding of God's selfrevelation to humankind.

In verses 16-34, Mary encounters the spirit (Gabriel) who assumes the likeness of a perfect man and identifies himself as a messenger of God. When he informs her that she would give birth to a blameless son, she remonstrates:

How can I have a son when no mortal has touched me, neither have I been unchaste? He said: So your Lord says: It is easy for Me. And (it will be) that We may make of him a revelation for mankind and a mercy from Us, and it is a thing ordained. And she conceived him, and she withdrew with him to a far place. And the pangs of childbirth drove her to the trunk of the palm tree. She said, "Oh, would that I have become nothing, forgotten!" Then (one) cried to her from below her, saying: Grieve not! Your Lord has placed a rivulet beneath you. And shake the trunk of the palm tree toward you. You will cause ripe dates to fall on you. So eat and drink and be consoled. And if you meet any mortal, say: I have vowed a fast to

6 Cf. Geoffrey Parrinder, Jesus in the Qur'an (Oxford: Oneworld, 1995), 95-96. 
the Compassionate, and may not speak this day to any mortal. Then she brought him to her own folk, carrying him. They said, "O Mary! You have come with an amazing thing. Oh sister of Aaron! Your father was not a wicked man nor was your mother a harlot." Then she pointed to him. They said: "How can we talk to one who is in the cradle, a young boy?" He spoke, "See! I am the servant of God. He has given me the Book and has appointed me a Prophet, and has made me blessed wherever I may be, and has enjoined on me prayer and almsgiving so long as I remain alive. And (has made me) dutiful toward her who bore me, and has not made arrogant, and unblessed. Peace on me the day I was born, and the day I die and the day I shall be raised alive!" Such was Jesus, son of Mary: (this is) a statement of the Truth concerning which they doubt.

Thus, Mary's initial doubt about the possibility of the virgin birth is considerably allayed by her personal encounter with the divine and her receptivity to being selected as an instrument of good in the world-against remarkable odds. Above all, poignantly etched in these verses is a loving mother-child relationship, tinged with desperation but also with unwavering servitude to God. The infant Jesus and his virgin mother appear to be pitted against a faithless world, which is all too eager to pass judgment on them. After all, who could possibly be more vulnerable to societal criticism than a barely pubescent girl and her child, born out of conventional wedlock? Yet God chose to act in history through the medium of these ostensibly contemptible, insignificant individuals, whose obedience to God's calling serves as a paradigm of faith and service for all humanity. And to send this message home, Jesus in the Qur'an is addressed primarily in terms of his relationship to his mother. In a run-of-themill, patriarchal society, the appellation 'Jesus, Son of Mary' must have raised some eyebrows and further underscored their marginal status. One need not be a feminist per se to appreciate how piety in these sacred narratives is rendered in non-gendered terms, and that foundational texts in both Islam and Christianity recognize goodness equally in men and women, as well as their equal agency in transforming the world. This perspective gets elided in the gendered constructions of piety and legal rights that later developed in both traditions, but is fully retrievable from the Qur'an and the Christian Bible. ${ }^{7}$ The tale of Mary and her child destined for greater things is above all a story of how

7 See in general Asma Barlas, "Believing Women" in Islam: Unreading Patriarchal Interpretations of the Qur'an (Austin, Tx: University of Texas, 2002), where she convincingly demonstrates how androcentric interpretations of the Qur'an have progressively masked its fundamental gender egalitarianism. 
a personal relationship with and fealty to God can transcend socially constructed categories and human systems of valuation. ${ }^{8}$

\section{Jesus as the Word of God and the Promised Messiah in Qur'anic Exegesis}

We now proceed to focus on another shorter but significant cluster of verses (Qur'an 3:45-47), referring to the birth of Jesus and to his various attributes. Since some of these attributes appear to be emphasized equally in Islam and Christianity, we will analyze them at greater length and present the views of a number of prominent Muslim exegetes. The verses under discussion state:

Behold the angels said: O Mary! God gives you good tidings of a Word from Him: his name will be Christ Jesus. The son of Mary, held in honor in this world and the hereafter and of (the company of) those nearest to God; He shall speak to the people in the cradle and in maturity. And he shall be one of the righteous. She said; O my Lord! How shall I have a son when no man has touched me? He said: Even so: God creates what He wills: when He has decreed a plan, He only says to it, Be-and it is!

These significant passages in the Qur'an from the third chapter titled Al Imran (the family of 'Imran) are particularly worthy of our attention because they are much cited in the literature comparing the position of Jesus in Islam and Christianity. Furthermore, to Christian ears, they sound similar to the description of the Annunciation that occurs in the Gospel of Luke (1:26-38). It will be a useful exercise for us to review quickly what some of the major Muslim commentators have said concerning several critical concepts pertaining to Jesus in these verses. Among these critical concepts are 'a word' (kalima) and the Messiah (al-masih), which remain contested notions among Muslim exegetes themselves, and which are also of great interest to Christian theologians who have similarly struggled to define these notions in relation to Jesus.

The well-known commentator al-Tabari (d. 923) understands 'a word' as referring to the good tidings imparted by God to Mary concerning 'a son for you whose name is the Messiah, 'Isa son of Mary.' He nevertheless presents an

8 For assessments and appreciations of Mary's exalted role in the Islamic tradition, see, for example, Aliah Schleifer et al., Mary, the Blessed Virgin of Islam (Louisville, KY: Fons Vitae, 1997); Mary F. Thurlkill, Chosen among Women: Mary and Fatima in Medieval Christianity and Shi'ate Islam (Notre Dame: University of Notre Dame Press, 2007). 
alternative interpretation, which understands 'a word' to be a reference to the divine command in the verse, "Be!"9 $\mathrm{Al}$-Tabari also points out that the famous Companion Ibn 'Abbas was of the opinion that the word (al-kalima) was a reference to Jesus himself, "who is the word from God."10 From these, Al-Tabari prefers the first explanation that he lists for kalima; that is, a reference to the good tidings that the angels brought to Mary about Jesus' prophethood and the annunciation that God would grant her a son (walad) without a husband, whose name would be the Messiah or the Christ." ${ }^{11}$ The full designation 'The Messiah, son of Mary,' continues al-Tabari, underscores the fact that Jesus was indeed the son of his mother, thus negating the claims of Trinitarian Christians as well as the accusations of impurity hurled at Mary by the Jews. ${ }^{12}$

As for the term 'The Messiah,' it is interpreted by al-Tabari as meaning that God Himself had wiped the sins off Jesus, on account of which 'the Messiah' may be equated with 'the Truthful One' (al-Siddiq). Others, however, have claimed that the name Messiah referred to someone who was touched by blessings (musiha bi'l-baraka). ${ }^{13}$

The noble status (wajihan) promised to Jesus is a reference to the elevated status that he would enjoy both in this world and the next, continues al-Tabari. Furthermore, the verse promises that he would be brought close to God on the Day of Judgment. His ability to speak to people from his cradle allowed him to defend his mother from the slanderous lies circulated about her, and it was a confirmation of his prophecy. Later, his speech to people as a mature man (kahlan) allowed him to convey the message of God as revealed to him, and to enjoin what is good and forbid what is wrong. According to one source, however, the reference to Jesus' speech as a mature man refers to his second coming when he will kill the anti-Christ. ${ }^{14}$ The final part of the verse, according to al-Tabari, is an affirmation that God can create ex nihilo; Jesus' birth by a virgin mother is an attestation to this divine attribute. ${ }^{15}$

A prominent exegete of the Seljuq period, Fakhr al-Din al-Razi (d. 1210), also has much to say on these two verses and hence a synopsis of his extensive commentary is offered here. He comments that just as the just ruler can be described as 'the shadow of God on earth' and 'the light of God,' implying that

$\begin{array}{ll}9 & \text { Al-Tabari, Jamic al-bayan, 3:268. } \\ 10 & \text { Ibid. } \\ 11 & \text { Ibid. } \\ 12 & \text { Ibid., 3:269. } \\ 13 & \text { Ibid., 3:269-70. } \\ 14 & \text { Ibid., 3:271-72. } \\ 15 & \text { Ibid., 3:272. }\end{array}$


he is a medium (sabab) for the appearance of the shadow of justice and the light of charity (al-ihsan), Jesus is similarly a medium for the appearance of the word of God, which serves to elucidate the Truth and dispel doubts and falsehoods. It is in this sense that Jesus is named 'the Word of God the Almighty.'16

To someone who might remonstrate that every human being must spring from a father, al-Razi is quick to refute this position by pointing to Qur'an 3:59, which states: "Indeed the likeness of Jesus in the presence of God is the likeness of Adam." Since Adam did not require a father to be born, Jesus does not require a father, either. Furthermore, it is pointed out that the world of animals is replete with examples of auto-genesis, as well as the reproduction of creatures unrelated to the parent. ${ }^{17}$ Interestingly, al-Razi seems to be appealing here to observable facts (as he understands them) and the world of nature to establish the miraculous nature of the birth of Jesus.

The phrase 'a Word from Him' contains the Arabic preposition min, which usually connotes a partitive sense ( $t a b^{\prime}$ id $)$; here, however, al-Razi explains that the preposition cannot be understood in a partitive sense, since that would imply a composite divine nature capable of being divided into constituent parts that could in turn be assembled into a whole. Composite bodies belong to created beings, "and God is far removed from that!" he asserts. Thus, the phrase 'a Word from Him' conduces to the meaning that the Word of God (Be!) was the origin of Jesus' coming into being and has nothing to do with the notion of incarnation. ${ }^{18}$

What, then, is the significance of the Arabic title al-Masih (the Messiah)? Al-Razi lists several possibilities that testify to the fecundity of the root $m s h$ in Arabic, which essentially means 'to rub, to anoint.' According to one source, Jesus earned the title because he would barely touch someone afflicted with disease and that person would be healed. Another source maintained that it was because Jesus had been anointed with a special blessed oil reserved for prophets, which serves as a sign for the angels to recognize all those who were born to be prophets. Yet another source commented that it was so because Gabriel is said to have brushed Jesus with his wings at the time of his birth so that he would be protected from being touched by Satan. ${ }^{19}$

As for the full appellation - the Messiah 'Isa, son of Mary—it indicates to al-Razi that 'Isa is his given name while 'the Messiah' is an honorific title, and

\footnotetext{
16 Al-Razi, al-Tafsir al-Kabir (Beirut: Dar Ihya al-Turath al-'Arabi, 1999), 3:221.

17 Ibid., 3:221-22.

18 Ibid., 3:222-23. Here, of course, al-Razi is specifically taking issue with the Christian position on the Logos and with incarnationists in general (al-Hayluliyya).

19 Ibid., 3:222-23.
} 
'son of Mary' is descriptive in the sense that it describes a fact. According to another source, the ascription specifically to Mary underscores that Jesus was born without a father, unlike other prophets, and that contributed to "an increase in his merit and enhancement of stature." 20

Jesus' noble stature in this world and the next is stressed in the Arabic word wajihan used in the verse in relation to him, continues al-Razi. As he explains, this adjective describes someone who is "possessed of [a high] station, honor, and esteem." It can also describe someone who is very generous. The same word was used to describe the status of Moses in Quran 33:69, both in this world on account of his function as a prophet, as well as in the next on account of his high rank in the presence of God. With regard to Jesus, it additionally referred to his ability to raise the dead, cure the leper, and heal the sick in this world, while in the next it referred to his status as an intercessor for his community, whose intercession will be accepted, as will that of the other great prophets. Furthermore, the epithet suggests that Jesus was innocent of the slurs cast at him by his enemies in this world, and was assured of an elevated status in the next because of "the plenitude of his merits" (kathrat thawabihi). ${ }^{21}$

From both al-Tabari's and al-Razi's exposition, it is therefore clear that neither the expression 'a Word from Him' nor 'the Messiah' corresponds to Christian notions of the Logos and Savior, respectively. These Qur'anic epithets applied to Jesus are to be understood in the context of his humanity and his role as a prophet selected by God in a long line of prophets, who had varying degrees of skills and aptitudes commensurate with the needs of their time and the people to whom they were sent. Many of the miracles attributed to Jesus in the Gospels are affirmed by the Qur'an and sometimes even elaborated upon by the exegetes, since they are credible manifestations of an all-powerful God who can directly intervene in history when He wants. Furthermore, Al-Razi's caveat that none of these Qur'anic attributes should be understood as having anything to do with Christian notions of incarnation or immanence is understandable within the Islamic conception of prophethood and its purpose in this world. Despite the similarity in the use of these terms in both traditions, the underlying assumptions about the meaning(s) of Jesus' mission on earth are strikingly different, particularly in the deployment of these epithets. However, the Quran's affirmation of a high status for Jesus in this world and the next would ring true for Christians, and his role as an intercessor in the hereafter on their behalf would sound welcomingly familiar.

$20 \quad$ Ibid., 3:223.

21 Ibid. 


\section{Other Qur'anic Attributes of Jesus}

Jesus' miracles (ayat) are well attested in the Qur'an. In addition to his ability to speak from the cradle, as already mentioned, he healed the leper and the blind man, raised the dead to life (Qur'an 5:110), and breathed life into birds of clay (Qur'an 3:49; 5:110) — deeds that no other prophet has carried out. These exceptional accomplishments attributed to Jesus are balanced in the Qur'an with unequivocal expressions of his servanthood to God and his human status as a messenger of God. Thus, Qur'an 4:172 states: “The Messiah will never scorn to be a servant of God, nor will the favored angels. Whoever scorns His service and is proud, all such will He assemble before Him."22 And again, in Qur'an 5:75 we find the assertion that: "The Messiah, son of Mary, was no other than a messenger, messengers the like of whom had passed away before him. And his mother was a virtuous woman. And they both used to eat (earthly) food."

Jesus is also considered the precursor prophet in the Qur'an, who announces the coming of Muhammad as the Messenger of God after him. In Qur'an 61:6, it is stated:

And when Jesus, son of Mary, said, "O Children of Israel! Lo! I am the messenger of God to you confirming that which was [revealed] before me in the Torah, and bringing good tidings of a messenger who will come after me, whose name is the Praised One (Ahmad).

Ahmad is a variant of the name Muhammad, and is regarded in Muslim apologetic literature as being the equivalent of the Comforter or the Paraclete mentioned in John 16:7, who will allegedly come after Jesus. The Greek word Paraclete is rendered as Periclytos, however, which yields the meaning of 'The Praised One,' which is the meaning of both Ahmad and Muhammad. ${ }^{23}$

From all the Qur'anic references to Jesus, it is perhaps the verses regarding his last days on earth that have sparked the most interest among Christian

22 Kenneth Cragg discerns a similarity between Qur'an 4:172 and the Christological hymn in Philippians, which refers to Jesus taking the form of a servant. Cragg states: "Both Scriptures affirm his being gladly 'servant' to God. That is their unity. The Qur'an however denies his 'Sonship' on the very grounds in which the Christian sees it to consist, namely a loving obedience to God." See his Jesus and the Muslim (London: George Allen \& Unwin, 1985), 30.

23 See a discussion of this in Parrinder, Jesus in the Qur'an, 96-100. 
students of Islam; this topic will now be briefly discussed. The locus classicus for the traditional Muslim understanding of Jesus' last days one earth is Qur'an 4:157-58, which states:

And because of their saying, "Behold, we have slain the Christ Jesus, the son of Mary, the messenger of God-but they slew him not nor crucified but it appeared so to them; indeed, those who disagree concerning it are in doubt thereof; they have no knowledge of it save pursuit of a conjecture; they slew him not for certain but God took him unto Himself. And God is Almighty, All-Wise.

The Qur'anic denial of the killing of Jesus affirms a basic theological premise in Islam, namely, that God does not let evil triumph over goodness (cf. Qur'an $5: 56 ; 9: 32 ; 58: 22 ; 61: 8)$. The wrongdoers may hatch relentless intrigues and plots against Him (Q 3:54; 5:110; cf. Q 8:30; 13:42) and His prophets, but their machinations will never prevail in the end. ${ }^{24}$ Jesus' ascension to heaven is a resounding affirmation of God's omnipotence and the vanquishing of His enemies. William A. Bijlefeld has called the Qur'anic denial of Jesus' death on the cross a "corrective denial," 25 which challenges the Jewish claim that they had crucified him and thereby proved that he was not the Messiah, as well as the Christian belief in the role of the cross in the redemptive atonement, although the cross is not specifically mentioned in these Quranic verses. The prevalent position among the overwhelming majority of Muslim exegetes and scholars is that Jesus was raised by God to His presence while still alive, and thus miraculously delivered from the harm intended by his enemies. ${ }^{26}$

24 Cf. Qur'an 3:54, which states: "And they (the disbelievers) plotted, and God plotted, and God is the best of the plotters."

25 Willem A. Bijlefeld, "Other Faith Images of Jesus: Some Muslim Contributions to Christological Discussions," in Christological Perspectives: Essays in Honor of Harvey K. McArthur, ed. Robert F. Berkey and Sarah A. Edwards (New York: Pilgrim Press, 1982), 204.

26 The rich and diverse exegetical tradition that grew up concerning these verses is discussed comprehensively by Todd Lawson in his The Crucifixion and the Qur'an: A Study in the History of Muslim Thought (Oxford: Oneworld Publications, 2009). For a detailed comparison between Muslim and Christian traditions on this topic, see A. H. Mathias Zahniser, The Mission and Death of Jesus in Islam and Christianity (Maryknoll, NY: Orbis Books, 2008); cf. Parrinder, Jesus in the Qur'an, 121. 


\section{Summary of the Points of Convergence and Divergence between Muslims and Christians Concerning Jesus}

To conclude this section on the Qur'anic depiction of Jesus and his prophetic mission, it is useful to summarize the main points concerning both the fundamental agreement and disagreement that exist between Islam and Christianity. As far as the points of convergence are concerned, both Islam and Christianity:

1) show profound respect for Jesus and affirm that while he lived in the world, he was pure and free of sin, and directly guided by God;

2) believe that Mary, Jesus' mother, was chaste, pure, and obedient to God;

3) assert that Mary was a virgin who conceived Jesus miraculously;

4) affirm that Jesus performed a number of miracles, including healing the sick and raising the dead.

Islam and Christianity, however, differ in the following ways:

1) While Christianity declares Jesus to be both human and divine, Islam rejects the notion of Jesus' divinity. As a result, Christians worship Jesus, while Muslims revere Jesus and accept him as an inspired prophet, based on the Qur'anic accounts of his life and acts;

2) Christians regard Jesus as the son of God, a concept that is not accepted by Muslims, who instead affirm that God does not procreate and have offspring.

3) Christianity asserts that Jesus was crucified. Contrastingly, Islam maintains that it only appeared as if Jesus was crucified, and that God instead raised him up to Himself.

4) Christianity maintains that Jesus died in order to redeem the original sin of humankind. For Muslims, however, Jesus does not serve as a redeemer since the concept of original sin is lacking in Islam. Instead, human beings individually earn their redemption through their belief in God and His revealed scriptures, as well as through their commission of righteous deeds. ${ }^{27}$

These points of convergence and divergence between Muslim and Christian beliefs regarding the life and mission of Jesus Christ have made for lively

27 Adapted from the list developed by Alan Godlas, available at http://islam.uga.edu/ jesusdif.html, last accessed on February 10, 2013. 
debates and conversations throughout the centuries, and continue strong in our own time. ${ }^{28}$

\section{Jesus in the Hadith Literature and Muslim Tradition}

In the standard hadith compilations - mainly the Six Books ${ }^{29}$ revered by Sunni Muslims-Jesus is primarily connected with the end of time. This is unique to the hadith literature, for the Qur'an makes no explicit reference to such an eschatological role for Jesus. Two Qur'anic verses — 4:159 and 43:61—are understood to allude to Jesus' second coming by the majority of exegetes, ${ }^{30}$ but this (at best) inchoate idea is fully developed only in the extra-Qur'anic literature. Thus, in one well-known hadith (a statement attributed to the Prophet Muhammad), the Companion Abu Hurayra relates:

The Messenger of God, peace and blessings be upon him, said, "By Him in whose hands my soul is, the son of Mary will soon descend among you as a just judge. He will break crosses, kill swine and abolish the poll-tax, and wealth will pour forth to such an extent that one will accept it and one prostration will be better than the world and what it contains." ${ }^{31}$

There are also hadiths that contain descriptions of the manner in which Jesus will fulfill his eschatological role of overcoming the anti-Christ, called al-Dajjal ('the Imposter') in Arabic, or more fully al-Masih al-Dajjal ('the false Messiah'). This figure is not mentioned in the Qur'an, but is prominent in the eschatological sections of hadith compilations. Here, Jesus' role is to come back during these end-times when the Dajjal makes his appearance, and eventually to slay him. One well-known hadith occurring in an authoritative collection describes in some detail the appearance of the Dajjal, claiming he will be a young man with curly hair and a defective eye, and who will emerge from between

28 Cragg's remark on the 'Christian potential of the Qur'an' is also worthy of note in this context; see his "Islamic Theology: Limits and Bridges," in The Gospel and Islam: A 1978 Compendium, ed. Don M. McCurry (Monrovia, CA: MARC, 1979), 31.

29 The Six Books are: the Sahih of al-Bukhari (d. 870); the Sahih of Muslim b. Hajjaj (d. 875); the Sunan of Ibn Maja (d. 886); the Sunan of Abu Da’ud (d. 888); the Sunan of al-Tirmidhi (d. 892); and the Sunan of al-Nasa'i (d. 915).

30 See Neal Robinson's discussion of these two verses in his Christ in Islam and Christianity (Albany, NY: State University of New York Press, 1991), 78-105.

31 English translation given by Muhammad Ata ur-Rahim, Jesus: Prophet of Islam (Norfold, England: Diwan Press, 1977). 
Damascus and Iraq and will be able to travel fast on earth. When the Prophet is asked how fast the Dajjal will be on earth, he replies:

Like rain backed by wind. He comes to a nation and they believe in him and accept (his message). He commands the sky to rain and it rains, and the earth to grow grass, and it grows. He provides them with plenty of wealth. He comes to another nation and they reject his message. He turns away from them and they become poor with nothing in their hands. He passes a remnant of an ancient city and tells her "take out your treasures." Its treasures follow him like bees, then he calls a man full of youth and strikes him with his sword, cutting him in two. Then he calls him and he (the youth) comes laughing with shining face (as if al-Dajjal was unable to kill him), at that moment God sends Jesus the son of Mary. He descends on the top of the white minaret at the east of Damascus, putting his hands on the wings of two angels. (He is so beautiful that) When he bows his head, water drops when he lifts it and shines like pearls. Any nonbeliever who finds his breath will be killed; his breath reaches as far as his sight. He pursues al-Dajjal and finds him at the gate of Lydda, then he kills him. Then a nation who was saved in the trial of the Anti-Christ comes to Jesus. He touches them and tells them about their levels in paradise. At that time God inspires Jesus that he has sent some people (Gog and Magog) that no one can defeat. And God says: "Take my servants to the mountain of Tour."32

While some Muslim theologians accept the content of the above hadith and others similar to it as literal references to specific events at the end of time, others detect in them broad allegorical references to a final showdown between good and evil, with a prominent role accorded to Jesus, who will end the frightful reign of the Dajjal and inaugurate the messianic era. He will fill the earth with justice and peace, and put an end to hatred and poverty. Jesus will then marry and beget children, and all will believe in him during this era of peace. ${ }^{33}$

Jesus also plays a prominent role in other, non-standard collections of delightful reports and anecdotes concerning biblical prophets who impart profound wisdom to a Muslim audience and instruct them in the proper ways of

32 Muslim, Fitan, \#110; translation given by Zeki Saritoprak, "The Legend of al-Dajjal (Antichrist): The Personification of Evil in the Islamic Tradition," Muslim World 93 (2003): 293-94.

33 Mahmoud M. Ayoub, "Towards an Islamic Christology, II: The Death of Jesus, Reality or Delusion," Muslim World 70 (1980): 120-21. 
the world. They form part of a literary genre known as the 'Tales of the Prophets' (Qisas al-anbiya'), which have proven to be very popular. A well-known historian of Islam, Tarif Khalidi, has collected many of these reports concerning Jesus and published them in a monograph entitled The Muslim Jesus. In this 'incarnation' of Jesus (to use the term in a non-theological sense), he is, as Khalidi describes it, at times "the ascetic, the prophet of the heart, the gentle teacher of manners, the mystic, the lord of nature, the healer of spiritual ills." ${ }^{34}$ One homiletic tradition states:

It was said that Jesus, son of Mary, peace be upon him, met a man and said to him, 'What are you doing?' He replied, 'I am devoting myself to God.' He said, 'Who is providing you with what you need?' He said, 'My brother.' Jesus then said, 'He is more devoted to God than you.'35

The report contains a gentle rebuke that faith and solitary worship without good deeds is less meritorious and less desirable than good deeds accompanied by faith. Hence, acts of charity and social interactions with one's fellow beings are a necessary complement to private devotion to God.

In another wise saying, Jesus counsels:

Time revolves around three days: a yesterday which has passed away and during which you have been admonished, a today which supplies your needs, and a tomorrow in which you do not know what is in store for you. All matters revolve around three things: a thing whose rightness has become apparent to you and which you must follow, a thing whose evil has become apparent to you and which you must shun, and a thing which appears uncertain to you and which you must defer to God. ${ }^{36}$

Jesus thus exhorts a Muslim audience to adopt a commonsensical approach to time - to learn from past mistakes, maximize today's potential, and not worry unduly about what tomorrow may bring. Furthermore, one must couple selfreliance with a fundamental reliance upon God and His beneficence. Jesus also

34 Quoted in the article "The Fifth Gospel: Tarif Khalidi and Jesus in the "Muslim Gospel," interview and commentary by Salim Tamari, available at www.jerusalemquarterly.org/ images/Articlespdf/15_gospel.pdf, last accessed on February 12, 2013.

Tarif Khalidi, The Muslim Jesus: Sayings and Stories in Islamic Literature (Cambridge, Mass.: Harvard University Press, 2003), 102.

$36 \quad$ Ibid., 77 . 
affirms a basic ethical tenet within Islam in this didactic report, namely, the upholding of what is good and right while avoiding what is evil and wrong.

Jesus is also invoked as a worldly-wise figure that warns against those who would yoke religious authority to worldly power, and admonishes the ostensibly pious who do not practice what they preach. Such a sad state of affairs is a harbinger of the end-times, for which he predicts:

At the end of time, there will be religious scholars who preach abstinence but do not themselves abstain, who encourage yearning for the afterlife but do not themselves yearn, who forbid visits to rulers but do not themselves desist, who draw near to the rich and distance themselves from the poor, who recoil from the lowly and fawn upon the mighty. They are the tyrants and the enemies of the Merciful God. ${ }^{37}$

The great affection and veneration that Muslims are encouraged to harbor towards Jesus and his mother is perhaps best encapsulated in a story about the fall of Mecca in $630 \mathrm{CE}$, preserved in the biography of the Prophet Muhammad by Ibn Hisham. According to Ibn Hisham, when Muhammad entered the Kaba, the shrine that housed the Meccan pantheon, he ordered that all its idols and paintings be cleansed or destroyed. One of the paintings held there was of the Virgin and the Christ-child. The Prophet is said to have approached this icon, covered it with his cloak, and did not allow it to be washed away. ${ }^{38}$ Whether this anecdote is true or apocryphal is irrelevant for our purposes. What matters is that the report is quite archaic and is extracted from some of the earliest historical narratives about the founding of the Muslim community. Its preservation and dissemination in the foundational literature of the Muslim community illustrates a fundamental reverence on the part of Muslims for the figure of Jesus, who along with his virgin mother epitomizes what it means to be a willing and humble servant of God.

\section{Jesus in Edifying and Sufi Literature}

Jesus is much beloved in devotional literature of all sorts, and is especially popular in Sufi literature. The celebrated magnum opus of Abu Hamid al-Ghazali

Ibid., 103-104. As Khalidi comments (ibid., 104), the behavior of these ulama' "echoes the behavior of the Pharisees rebuked by Jesus in Matthew, and merits a more direct censure of Muslim scholars who sell their integrity in order to gain favor with rulers, a reversal of the true vocation of scholars." 
(d. 1111), Ihya 'ulum al-din, contains several reports concerning Jesus that emphasize his proclivity for asceticism and otherworldly spirituality. One such report relates: "Jesus lay down one day with his head upon a stone. Satan, passing by, said: 'O Jesus, you are fond of this world.' So Jesus took the stone and cast it from under his head, saying: "This be yours, together with this world. "39

The Sufi's constant efforts to purify himself or herself by forsaking the vain things of this world and its vain company, all of which distract from the remembrance of God, are exemplified by Jesus and his abstemious ways. To illustrate this, we can once again extract an edifying anecdote from al-Ghazali's Ihya, which relates what Jesus once said to his disciples:

"O disciples, seek the love of God by your hatred of sinners; seek to be near Him by [doing] that which distances you from them; and seek His favor by being angry with them." He [Malik $]^{40}$ said, "I do not know which [commandment] he began with." They said, "O Spirit of God, whose company then shall we keep?" He replied, "Keep the company of him whose sight reminds you of God, whose speech increases your knowledge, whose deeds make the afterlife desirable."41

Jesus, in al-Ghazali's depiction, is a very human Jesus, who accepts his lot in life as divinely ordained, experiences frustration and despair, and makes no attempt to use physical force to overcome any adverse situation. His gentleness and patient resignation are invoked by al-Ghazali as a model to be emulated by mystical practitioners, and he encourages them to pray the way Jesus did:

O God I have arisen from my sleep and am not able to ward off that which I hate and am not able to possess the benefit of that which I desire and the matter rests in hands other than mine. And I have pledged myself to my work and there is no man so poor as I am. O God, let not my enemies rejoice over me and let not my friends deal ill with me, and let not my afflictions come to me in matter of my religion. And do not allow the world to occupy my care, and do not allow the unmerciful to overcome me, O Thou Eternal! ${ }^{42}$

\footnotetext{
39 Samuel Zwemer, "Jesus Christ in the Ihya of al-Ghazali," The Muslim World 7.2 (1917): $144-45$.

40 This is Malik b. Mighwal (d. 776), who was an early traditionist from Kufa and transmitted many sayings attributed to Jesus.

41 Khalidi, Muslim Jesus, 57.

42 Ibid., 150.
} 
Jesus' meekness and ascetic piety are celebrated by other Sufis as well, as he constitutes a model and guide for their way of life, centered on a renunciation of the wealth and luxury of this world. This is the path to true happiness, says Jalal al-Din Rumi (d. 1273), as confirmed by Jesus' ministry, which he describes as follows:

From all sides the people ever thronged Many blind and lame, halt and afflicted At the door of the house of 'Isa at dawn, That with his breath he might heal their ailments.

As soon as he had finished his orisons?....

He spoke to them saying, "O stricken ones,

The desires of you all have been granted by God,

Arise, walk without pain or affliction,

Acknowledge the mercy and beneficence of God. ${ }^{43}$

In mystical literature, Jesus is often called the 'man of sorrows,' though he is also considered a prophet who through exemplary piety and abstinence has achieved nearness to God-a trait that Sufis strive to emulate. ${ }^{44}$ Thus, the wellknown Persian Sufi poet Mahmud Shabistari (d. 1340) describes the pious mystic as one who "obtains release from his own knowledge, and, like the prophet Jesus, he becomes near to God. He gives up his existence utterly to be plundered and in the steps of the most pure he ascends." ${ }^{m 5}$

Ibn 'Arabi (d. 1240), a celebrated mystical philosopher from the thirteenth century, went on to call Jesus 'the Seal of the Friends of God' on account of having achieved the highest knowledge of God. In Ibn 'Arabi's understanding, a wali (literally 'friend,' usually translated into English as 'saint') is one who on account of his knowledge of God realizes his essential unity with God the Creator (Arabic, wahdat al-wujud; i.e., monism). Furthermore, Ibn 'Arabi distinguishes between general prophecy and particular prophecy. General prophecy, which is identified with 'friendship with God' (wilaya), refers to "those personal laws which are entrusted to people 'created for Himself, chosen for His service and selected from among His worshipers for His presence." "46 That

\footnotetext{
43 Translation given by Kenneth Cragg, Jesus and the Muslim: An Exploration (Oxford: Oneworld, 1999), 6o-61.

44 Ibid., 59-63.

45 Ibid., 60.

46 Andreas D'Souza, "Jesus in Ibn 'Arabi's Fusus al-hikam," Islamo-Christiana 8 (1982): 196.
} 
is, the Friends of God (awliya') receive certain personal laws directly from God. These personal laws deal with the recipients' relationships to God, and hence are manifested primarily in their worship of God and cannot be propagated. Particular prophecy, on the other hand, which includes both the prophets and the apostles, is related to the institution of laws. Being temporal, it has come to an end with Muhammad, who is 'the Seal of the Prophets.' Therefore, no new law will be proclaimed to abrogate, contradict, or complement the law of Muhammad. ${ }^{47}$ Whereas prophethood and apostleship are temporal, wilaya is eternal and continues into the future. Being eternal, wilaya (or friendship with God) is regarded by Ibn 'Arabi as being of a higher degree than prophethood and apostleship. Thus, Jesus will return to the earth during the end-times as the seal of the Friends of God, for there will be no more awliya after him. ${ }^{48}$

\section{Jesus among the Shi'a}

The Shi'a, like Sunni Muslims, hold Jesus in great esteem. He is regarded as one of the five most important prophets, called the 'Prophets of Power,' the other four being Noah, Abraham, Moses, and Muhammad. However, for the Shi'a, Jesus is not only a prophet but also an imam - that is to say, a spiritual leader and a vicegerent of God. As an imam he is endowed with esoteric knowledge and belongs to both the exoteric and esoteric cycles of prophethood. In Shici Islam, the imams are greater and more exalted than all the prophets who came prior to the Prophet Muhammad. ${ }^{49}$ The Shica also tend to see certain aspects of Jesus' person and life reflected in their imams. For example, the Shi'a believe in the priority of the imams as God's primordial Word and Spirit, and that it is through the imams, and for their sake, that everything was created. According to Mahmoud Ayoub, the conception of Jesus as the divine Logos and God's spirit has probably contributed to the Shici view that the imams are God's primordial Word and Spirit. ${ }^{50}$

Both the first imam 'Ali and the second imam, his son al-Husayn, are considered to be the embodiment of the betrayed and suffering martyr. Al-Husayn, on account of the events at Karbala, in particular is regarded as mirroring Jesus

\footnotetext{
47 Ibid., 197-98.

48 Ibid., 199-200.

49 Ibid., 62.

50 Mahmoud Ayoub, "Towards an Islamic Christology: An Image of Jesus in Early Shici Muslim Literature," The Muslim World 46 (1976): 167-168.
} 
in his sufferings. Several reports recorded by Shi'a scholars relate how Jesus presciently lamented the future martyrdom of al-Husayn. According to one of these accounts, a lion once blocked Jesus and his disciples when they arrived at Karbala during their peregrinations. When Jesus asked the lion the reason for his behavior, the lion said: "Here will be killed the grandson of the Prophet Muhammad and I will not let you pass until you curse his murderers." Jesus then inquired about the would-be murderers of al-Husayn, to which the lion responded: "He is the accursed of the inhabitants of the heavens and earth, of the beasts of the fields, and the fish of the sea, he is Yazid."51 Lifting up his hands to the heavens, Jesus then cursed the murderer and his companions four times, and the disciples responded with "Amen." The lion then allowed them to proceed. ${ }^{52}$

Although the Shi'a do not claim that al-Husayn was born of a virgin mother, some among them believe that both al-Husayn and Jesus had a miraculous nativity because each was in the womb for only six months. Like Jesus, al-Husayn had also praised God from his mother's womb, and was similarly capable of raising the dead. Some among the ghulat - that is, Shici extremists outside the mainstream tradition-have gone even as far as to say that al-Husayn, like Jesus, did not die and was miraculously raised to heaven instead. ${ }^{53}$

Because of the striking similarities in their lives and earthly roles, the Shici in general regard al-Husayn to be Jesus' brother. Although al-Husayn was not a prophet, his position as an imam conferred on him a status similar to prophethood in terms of cosmic importance. This is signaled in a report emanating from the fifth Shi'i imam, Muhammad al-Baqir, who stated:

On the night that 'Ali was killed, under every stone that was turned there was found congealed blood. The same thing happened also when Aaron (Harun), brother of Moses, and Joshua, son of Nun, were killed; when Jesus was lifted up to heaven, and when Simon Peter (Sham'un al-Safa) and Husayn, son of 'Ali, were killed. ${ }^{54}$

$5^{1} \quad$ Yazid was the second Umayyad caliph during whose reign al-Husayn and his family were killed on the battlefield at Karbala' in Iraq.

52 Mahmoud Ayoub, Redemptive Suffering in Islam: A Study of the Devotional Aspects of Ashura in Twelver Shi'asm (Berlin: De Gruyter, 1978), 35.

53 Ibid., 36 .

54 Ibid., 34-35. 


\section{Modern Views}

Moving on to the modern period, we find that there is a tendency among a number of modern Muslim authors to emphasize the universality of Jesus' prophethood, in order to find common ground between Islam and Christianity on the basis of shared universal ethics that can bridge theological differences. Furthermore, the universality of Jesus' mission can be justified on the basis of the Qur'an; verse 2:191, after all, describes Jesus as an aya or 'a sign' for all peoples, in parallel with the New Testament (John 4:1-26 and Luke 7:1-10), which describes Jesus' ministry as embracing not only the Jews but also the Samaritans, Romans, Phoenicians, and Greeks.

In his book 'Abqariyyat al-Masih ("The Genius of the Messiah"), the Egyptian author 'Abbas al-'Aqqad (d. 1964) portrays Jesus as a prophet-teacher whose message has universal significance. Although Jesus and his disciples began their mission in Galilee within the traditional Jewish ethno-religious framework, they eventually embraced universal humanity as they progressively defied the Jewish establishment. Al-'Aqqad emphasizes that the universality of Jesus' mission inheres in his ethical message, which he fought to promote by launching a spiritual warfare against his own baser instincts and vigorously counseling others to do likewise. As he explains it:

It is quite clear that we must recognize that the Messiah is of the same material as his companions, the great prophets, for whom spiritual warfare knew no truce. This continual struggle against themselves condemns them to anguish and brings them to question at the deepest level their own faithfulness or unfaithfulness to the path which God has chosen for them. It is undoubtedly this warfare which is expressed in the gospel narrative of the temptation. Christ is victorious in this trial, like the other prophets, in agony, struggle and anguished acceptance. ${ }^{55}$

Al-Aqqad emphasizes the social justice component of Jesus' universal message, as well as the transformational nature of this project. He was solicitous towards women and the poor, and was charitable and forgiving toward all, including his enemies, notes al-'Aqqad. Jesus the Christ succeeded primarily in a spiritual vein in conveying his message, continues our author, in comparison

55 Translation given by Penelope Johnstone, "Christ Seen by Contemporary Muslim Writers," Encounter 87 (1982): 5 . 
to the Prophet Muhammad, who was successful both spiritually and socially in conveying and establishing his message for all of humanity. ${ }^{56}$

Another Muslim author, Khalid Muhammad Khalid, emphasizes the complementarity of the missions of Muhammad and Jesus in his book Ma'an 'ala al-tariq: Muhammad wa l-masih ("On the Road Together: Muhammad and the Messiah"). He cites the hadith that describes the brotherhood of the prophets as a proof-text, and refers to Jesus' role as the precursor prophet and the eschatological prophet. Thus, Jesus is a necessary complement to Muhammad's prophethood since he had foretold the latter's coming as 'the Seal of the Prophets,' while Muhammad is a necessary complement to Jesus' prophethood since he had announced the latter's second coming as the eschatological prophet. Khalid comments that this complementarity should be an invitation for Christians and Muslims to work together in order to improve human society and further the common good. ${ }^{57}$

\section{Conclusion}

Khalid's message is often repeated in our own times - the way forward for Christians and Muslims is to emphasize the universality of the ethics they share and their common reverence for Jesus, rather than focusing on the theological differences that separate them. In 2009, Robert Shedinger, a Lutheran academic, published a book provocatively titled Was Jesus a Muslim?,58 in which the author explores the question of whether Jesus can be considered a Muslim. His ultimate answer is yes-for if Jesus is regarded primarily as someone who was supremely concerned with social justice, then he was as much of a Muslim as Muhammad or, one could add, as any other prophet was. Perhaps this is shocking to some Christian ears, but to Muslims it reassuringly affirms the commonality of the messages imparted by righteous men chosen by God to be His devoted servants. As we recall, 'Abbas al-'Aqqad had also similarly emphasized the ethical message of Christianity, which was the basis of its common ground with Islam. Even though Muslims reject for the most part the christological doctrines concerning the nature of Christ, they nevertheless embrace him as an essential part of Islam, whose existence and ministry made possible the culminating mission of the Prophet Muhammad.

\footnotetext{
56 Al-Aqqad, Abqariyyat al-Masih (Cairo: Dar Nahdat Misr, 1973), passim.

57 Cragg, Jesus and the Muslim, $5_{2} \mathrm{ff}$.

58 Robert Shedinger, Was Jesus a Muslim? Questioning Categories in the Study of Religion (Minneapolis, MN: Fortress Press, 2009).
} 
It would be fitting to end this essay by quoting Tarif Khalidi, who simply and elegantly explains why Jesus remains the common link between Muslims and Christians, and why their common love for him will continue to bring them together, despite critical doctrinal differences. Khalidi memorably writes:

So: I think it can safely be shown that Islamic culture presents us with what in quantity and quality are the richest images of Jesus in any nonChristian culture. No other world religion known to me has devoted so much loving attention to both the Jesus of history and to the Christ of eternity. This tradition is one that we need to highlight in these dangerous, narrow-minded days. The moral of the story seems quite clear: that one religion will often act as the hinterland of another, will lean upon another to complement its own witness. There can be no more salient example of this interdependence than the case of Islam and Jesus Christ. And for the Christian in particular, a love of Jesus may also mean, I think, an interest in how and why he was loved and cherished by another religion. ${ }^{59}$

Given the increasing dialogic encounters between contemporary Christians and Muslims, Khalidi's comments are particularly appropriate and point the way ahead for more productive conversations regarding the meanings of the life and mission of the Messiah 'Isa, which resonate strongly in both traditions.

59 Remarks posted at www.bbc.co.uk/religion/religions/islam, last accessed on 2/15/2013. 